\title{
Understanding heparin-induced thrombosis: A brief review
}

\author{
Mariela Irabien-Zúñiga, Edgar A. Rojas-Guerrero, and David Gómez-Almaguer \\ Hematology Service, Facultad de Medicina, Hospital University “Dr. José Eleuterio González", Universidad Autónoma de Nuevo León, Monterrey, \\ Nuevo Leon, Mexico
}

\begin{abstract}
Heparin has been the first line for treatment and prevention of thrombosis for a while. However, one of its non-hemorrhagic effects remains noticeable: heparin-induced thrombocytopenia, mediated by antibodies directed to complexes of platelet factor, and heparin. Binding to platelet FcyRIIA receptors initiates platelet aggregation and its thrombotic effect. Incidence of heparin-induced thrombocytopenia (HIT) ranges from $<0.1 \%$ to $7 \%$. Diagnosis can be made clinically in patients with thrombocytopenia/thrombosis currently on heparin. Treatment includes suspension of heparin and the administration of non-heparin anticoagulants. Vaccine-induced thrombocytopenia/thrombosis is a complication described after administering vaccines developed to prevent severe coronavirus disease (severe acute respiratory syndrome coronavirus 2). It has a remarkable resemblance to HIT. Therefore, they have been studied clustered. Enzyme-linked immunosorbent assays, a modified platelet-activation test, are used for its diagnosis. Treatment consists of early administration of high-dose intravenous immunoglobulin in conjunction with non-heparin anticoagulation.
\end{abstract}

Keywords: Thrombosis. Clots. Heparin. Vaccination. Coronavirus disease-19.

Heparin, a member of the glycosaminoglycan family, is one of the oldest pharmaceuticals that is still on the market, having celebrated 100 years of its discovery in $2016^{1}$. Due to its good efficacy, it is one of the few drugs that have not been overshadowed by advances in new drug development and remains as one of the most prescribed drugs nowadays ${ }^{2}$. Its main function is to inhibit clot and thrombi formation and it has been the first line for treatment and prevention of thrombosis for a while ${ }^{3}$.

However, one of its non-hemorrhagic adverse effects remains noticeable; heparin-induced thrombocytopenia (HIT) divided into type one and type two $0^{4,5}$. Type $1 \mathrm{HIT}$ is a transitory heparin-associated thrombocytopenia that is not mediated by immune complexes and not associated with thrombosis ${ }^{6}$. Type 2 is a clinically significant syndrome mediated by antibodies to complexes of platelet factor (PF4) and heparin. Incidence of HIT ranges from $<0.1 \%$ to $7 \%$, and results might deviate depending on the type of heparin used, factors associated with procedures, and intrinsic factors of each patient ${ }^{7}$. Furthermore, risk factors such as an age $>60$, the use of non-fractioned heparin versus low weight heparin, and female sex have been related to $\mathrm{HIT}^{8}$.

Thrombocytopenia can be defined as a reduction of platelets with levels lower than $150 \times 10^{9} / \mathrm{L}$, a reduction of $50 \%$ or more from baseline platelets, or both ${ }^{9,10}$. Mechanisms involved in the HIT phenomenon are mainly performed by antibodies directed to complexes of PF4 and heparin ${ }^{11,12}$. This immune reaction could produce thrombocytopenia and arterial or venous thrombosis, which is the most frequent manifestation, binding to the platelet FcyRIIA receptor, which initiates platelet activation and promotes tissue factor synthesis

\section{Correspondence:}

*David Gómez-Almaguer

E-mail dgomezalmaguer@gmail.com
Available online: 18-10-2021

Date of reception: 03-06-2021

Date of acceptance: 29-06-2021 DOI: 10.24875/RMU.21000026

\section{Medicina Universitaria. 2021;23(3):103-106} www.medicinauniversitaria.org

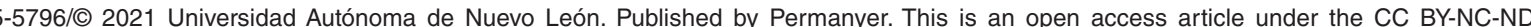
license (http://creativecommons.org/licenses/by-nc-nd/4.0/). 
contributing to platelet aggregation and its thrombotic effect ${ }^{13}$.

Diagnosis of HIT thrombosis is clinical, and as in many diseases, the first step is suspicion, since a patient with thrombocytopenia and/or thrombosis currently on heparin administration should make the physician suspect HIT. However, it is important to note that in many cases, thrombocytopenia is commonly encountered in daily clinical practice from asymptomatic patients to critically ill patients ${ }^{6}$, including thrombocytopenia induced by surgery, cardiac bypass, cardiac assist devices, liver disease, alcohol abuse, post-transfusion purpura, and passive alloimmune thrombocytopenia, among others. Therefore, the combination of thrombocytopenia plus thrombosis is the key to the diagnosis.

Treatment of HIT includes the immediate suspension of heparin, and the administration of a direct inhibitor of thrombin (e.g., argatroban) associated with a Vitamin $\mathrm{K}$ antagonist (e.g., warfarin). Other options for treatment include bivalirudin, danaparoid, and fondaparinux ${ }^{7}$.

Prophylactic platelet transfusion should be avoided in patients at low risk, as the risk of thrombosis increases with every transfusion ${ }^{8}$. According to the 2018 guidelines, when HIT is suspected, physicians should perform the $4 \mathrm{~T}$ Score (4Ts), a tool to predict the risk of thrombocytopenia (Table 1). The 4Ts score is the sum of the values for each of the four categories. A score of 1 - 3 represents a low probability of HIT, a score of 4 - 5 represents an intermediate probability of HIT, and a score of 6 - 8 represents a high probability of HIT ${ }^{14,15}$.

Depending on the risk obtained with this score, a diagnostic test is selected. For instance, an immunoassay is recommended if there is an intermediate or high probability according to the 4Ts score. If this study is positive, the next step is to perform a functional assay ${ }^{7}$. On the other hand, if the risk is low, no test is necessary.

With the emergence of several vaccines developed to prevent severe coronavirus 2 (severe acute respiratory syndrome coronavirus 2), concerns about vaccine-induced adverse events such as thrombocytopenia and thrombosis were raised ${ }^{16}$. Furthermore, COVID-19 itself can elevate the risk of arterial or venous thromboembolism in about $20 \%$ of hospitalized patients ${ }^{17-19}$. Even though the Vaxzevria (formerly known as Oxford-AstraZeneca) vaccine, based on adenovirus, has been under the spotlight because of vaccine-induced thrombotic thrombocytopenia (VITT), mRNA vaccines such as Pfizer and Moderna also have reports of thrombocytopenia after immunization ${ }^{20}$. On further analysis, the proportion of thrombocytopenia
Table 1. 4T's score. 4T Clinical Scoring System

\begin{tabular}{|c|c|c|c|}
\hline 4T's & 2 points & 1 point & 0 point \\
\hline Thrombocytopenia & $\begin{array}{l}\text { Platelet count } \\
\text { fall }>50 \% \text { and } \\
\text { platelet count } \\
\text { nadir } \leq 20 \%\end{array}$ & $\begin{array}{l}\text { Platelet count } \\
\text { fall } 30-50 \% \text { or } \\
\text { platelet nadir } \\
10-19\end{array}$ & $\begin{array}{l}\text { Platelet } \\
\text { count fall } \\
<30 \% \text { or } \\
\text { platelet } \\
\text { nadir }<10\end{array}$ \\
\hline Timing & $\begin{array}{l}\text { Clear onset } \\
\text { between days } \\
5 \text { and } 10 \text { or } \\
\text { platelet fall } \\
\leq 1 \text { day (prior } \\
\text { heparin } \\
\text { exposure } \\
\text { within } 30 \\
\text { days) }\end{array}$ & $\begin{array}{l}\text { Consistent } \\
\text { with days 5-10 } \\
\text { fall, but nor } \\
\text { clear (e.g., } \\
\text { missing } \\
\text { platelet } \\
\text { counts); onset } \\
\text { after day 10; or } \\
\text { fall } \leq 1 \text { day } \\
\text { (prior heparin } \\
\text { exposure } \\
30-100 \text { days } \\
\text { ago) }\end{array}$ & $\begin{array}{l}\text { Platelet } \\
\text { count fall } \\
<4 \text { days } \\
\text { without } \\
\text { recent } \\
\text { exposure }\end{array}$ \\
\hline $\begin{array}{l}\text { Thrombosis or } \\
\text { other sequelae }\end{array}$ & $\begin{array}{l}\text { New } \\
\text { thrombosis } \\
\text { (confirmed); } \\
\text { skin necrosis: } \\
\text { acute } \\
\text { systemic } \\
\text { reaction post } \\
\text { intravenous } \\
\text { unfractionated } \\
\text { heparin (UFH) } \\
\text { bolus }\end{array}$ & $\begin{array}{l}\text { Progressive or } \\
\text { recurrent } \\
\text { thrombosis; } \\
\text { non- } \\
\text { necrotizing } \\
\text { (erythematous) } \\
\text { skin lesions; } \\
\text { Suspected } \\
\text { thrombosis } \\
\text { (not proven) }\end{array}$ & None \\
\hline $\begin{array}{l}\text { Other causes of } \\
\text { thrombocytopenia }\end{array}$ & Non apparent & Possible & Definite \\
\hline
\end{tabular}

cases (0.80 per million doses) reported to the Vaccine Adverse Event Reporting System (VAERS) does not suggest a safety burden due to mRNA COVID-19 vaccines (Pfizer and Moderna) at this time ${ }^{20,21}$. Therefore, the Astra Zeneca vaccine has been at risk of temporary and even possible permanent suspension ${ }^{22}$. Other countries such as Denmark, Norway, Iceland, and recently, Canada also suspended the vaccine until further research was performed ${ }^{23}$. As a result of this, controversy exists around using the vaccine, with institutions such as the World Health Organization and EMA stating vaccine benefits outweigh risks ${ }^{24}$. The risk of thrombosis was superior in younger age groups, reporting 1.1 serious adverse events for every 100,000 immunized people in the age group between 20 and 29 versus 0.2 for every 100,000 in those aged between 60 and 69. In comparison, in women receiving hormonal contraceptives, the risk of thrombosis is 60 cases per 100,000 , and the risk of fatal pulmonary embolism is about 1 case per 100,00025. 
Central venous sinus thrombosis (CVST) is an uncommon form of stroke, representing only $0.5-1 \%$ of all strokes and appearing more commonly in young peo$\mathrm{ple}^{26}$. Prothrombotic conditions such as the presence of antiphospholipid, anticardiolipin, factor V Leiden mutation and resistance, and more frequently found, pregnancy and puerperium have also been associated ${ }^{27,28}$. Signs and symptoms may be confused with multiple neurological disorders, so suspicion is always very important. The presentation includes headache, focal neurological presentations, nerve palsies, and increased intracranial pressure with papilledema, among others ${ }^{29}$.

The Food and Drug Administration and Centers for Disease Control and Prevention suggested pausing the use of the Janssen vaccine after reports of cases of CVST with thrombocytopenia. VAERS received 13,725 adverse events from Janssen vaccine recipients; $13,294(97 \%)$ classified as nonserious; and $343(3 \%)$ as serious adverse events, including three reports of nonCVST thrombosis with thrombocytopenia syndrome (TTS) with no fatalities. Two of the TTS cases occurred in women between 30 and 39 and just one of them between 50 and 59. On April 25, 14 CSVT cases were confirmed, giving 17 TTS cases $^{30}$.

VITT studies report this adverse event mostly in women younger than 50 years of age and uncommon localization of the thrombi such as the cerebral venous sinus, portal, splanchnic, and hepatic veins. Clinical presentation of moderate to severe TTS complications from Astra Zeneca begins approximately 1 to 2 weeks after vaccine immunization ${ }^{31}$. It resembles HIT with high-level antibodies to PF4-polyanion complexes, but it is less dependent on physiological levels of heparin and less sensitive to inhibition with high-dose heparin ${ }^{32}$. The most accepted etiology of this effect is similar to the one involved in HIT with a median platelet count of $20-30 \times 10^{9} / L^{33}$. As a result of this, massive activation of platelets occurs ${ }^{34}$.

Recommendations for laboratory investigation in suspected VITT should always begin with a complete blood count, prothrombin time, activated thromboplastin time, fibrinogen, and D-Dimer ${ }^{35}$. Reported laboratory findings between patients include elevated levels of D-dimers, PF 4 antiplatelet antibodies, and corona spike protein antibodies, combined with thrombocytopenia ${ }^{36}$. After this, a binding assay such as the enzyme-linked immunosorbent assay (ELISA), which is widely available, should be performed to detect PF 4 antibodies. Alternatives to ELISA include a serotonin release assay, and a heparin-induced platelet activation assay, among others. A negative assay discards HIT and VITT. Some authors state that confirmation may be needed if the assay result is a moderate or weak positive, and thus it is recommended to perform a modified platelet-activation test ${ }^{37}$. Concerning therapy, Thaler et al. reported the first successful treatment of VIPIT secondary to AstraZeneca's immunization, using early administration of high dose IVIG $1 \mathrm{~g} / \mathrm{kg}$ body weight ${ }^{31,34}$ in conjunction with non-heparin anticoagulation (such as rivaroxaban and apixaban) to interrupt the prothrombotic process. However, it is important to note that heparin anticoagulation may be indicated if a functional test discards the risk of $\mathrm{HIT}^{31,34,37}$. When CVST is suspected, a tomography with venogram or magnetic resonance is recommended ${ }^{29}$. Consultation with hematology specialists is, in all cases, strongly recommended ${ }^{33}$.

A risk-benefit analysis was performed in cases such as the Janssen vaccine, and even though the balance varied by age and sex, the benefits outweighed the risks for all ages 18 and up.

The resemblance between HIT and the pathophysiology of VITT is remarkable. Further research is needed as the COVID-19 pandemic is still ongoing. It is important to emphasize the clinical presentation of VITT to establish new guidelines for early diagnosis and management, update our comprehension with randomized clinical trials, and gather current data from VAERS.

\section{Funding}

This study was locally funded.

\section{Conflicts of interest}

The authors declare that there are no conflicts of interest.

\section{Ethical disclosures}

Protection of human and animal subjects. The authors declare that no experiments were performed on humans or animals for this study.

Confidentiality of data. The authors declare that no patient data appear in this article.

Right to privacy and informed consent. The authors declare that no patient data appear in this article.

\section{References}

1. Subramanian $\mathrm{S}$. The story of heparin. Indian $\mathrm{J}$ of Vasc and Endovasc Surg. 2017;4:198

2. Wardrop D, Keeling $D$. The story of the discovery of heparin and warfarin. Br J Haematol. 2008;141:757-63. 
3. Lima M, Rudd T, Yates E. New applications of heparin and other glycosaminoglycans. Molecules. 2017;22:749.

4. Arepally GM. Heparin-induced thrombocytopenia. Blood. 2017;129:2864-72.

5. Greinacher A. Heparin-induced thrombocytopenia. N Engl J Med. 2015;373:252-61.

6. Ali N, Auerbach HE. New-onset acute thrombocytopenia in hospitalized patients: pathophysiology and diagnostic approach. J Community Hosp Intern Med Perspect. 2017:7:157-67.

7. Cuker A, Arepally GM, Chong BH, Cines DB, Greinacher A, Gruel Y, et al. American society of hematology 2018 guidelines for management of venous thromboembolism: heparin-induced thrombocytopenia. Blood Adv. 2018;2:3360-92

8. Vázquez D, Marques MR, de Sousa SM, Duarte M, Miguel S, González ML. Trombocitopenia inducida por heparina: cuando las plaquetas bajas pueden causar trombosis. MCP. 2019;2:112-4.

9. Oliveira GB, Crespo EM, Becker RC, Honeycutt EF, Abrams CS, Anstrom KJ, et al. Incidence and prognostic significance of thrombocytopenia in patients treated with prolonged heparin therapy. Arch Intern Med. 2008;168:94-102

10. Buckley MF, James JW, Brown DE, Whyte GS, Dean MG, Chesterman $\mathrm{CN}$, et al. A novel approach to the assessment of variations in the human platelet count. Thromb Haemost. 2000;83:480-4.

11. Arepally GM, Mayer IM. Antibodies from patients with heparin-induced thrombocytopenia stimulate monocytic cells to express tissue factor and secrete interleukin-8. Blood. 2001:98:1252-4.

12. Linkins LA. Heparin induced thrombocytopenia. BMJ. 2015;350:g7566.

13. Pouplard C, lochmann S, Renard B, Herault O, Colombat P, Amiral J et al. Induction of monocyte tissue factor expression by antibodies to heparin-platelet factor 4 complexes developed in heparin-induced thrombocytopenia. Blood. 2001;97:3300-2.

14. Cuker A, Gimotty PA, Crowther MA, Warkentin TE. Predictive value of the 4Ts scoring system for heparin-induced thrombocytopenia: a systematic review and meta-analysis. Blood. 2012;120:4160-7.

15. Lo GK, Juhl D, Warkentin TE, Sigouin CS, Eichler P, Greinacher A Evaluation of pretest clinical score (4 T's) for the diagnosis of heparin-induced thrombocytopenia in two clinical settings. J Thromb Haemost. 2006;4:759-65.

16. Cines DB, Bussel JB. SARS-CoV-2 vaccine-induced immune thrombotic thrombocytopenia. N Engl J Med. 2021;384:2254.

17. Al-Ani F, Chehade S, Lazo-Langner A. Thrombosis risk associated with COVID-19 infection. A scoping review. Thromb Res. 2020;192:152-60.

18. Hanff TC, Mohareb AM, Giri J, Cohen JB, Chirinos JA. Thrombosis in COVID-19. Am J Hematol. 2020;95:1578-89.

19. Ackermann M, Verleden SE, Kuehnel M, Haverich A, Welte T, Laenger F, et al. Pulmonary vascular endothelialitis, thrombosis, and angiogenesis in Covid-19. N Engl J Med. 2020;383:120-8.

20. Lee E-J, Cines DB, Gernsheimer T, Kessler C, Michel M, Tarantino MD, et al. Thrombocytopenia following Pfizer and Moderna SARS-CoV-2 vaccination. Am J Hematol. 2021:96:534-7.

21. Welsh KJ, Baumblatt J, Chege W, Goud R, Nair N. Thrombocytopenia including immune thrombocytopenia after receipt of mRNA COVID-19 vaccines reported to the vaccine adverse event reporting system (VAERS). Vaccine. 2021;39:3329-32.
22. Vogel G, Kupferschmidt K. New problems erode confidence in AstraZeneca's vaccine. Science. 2021;371:1294-5

23. Wise J. Covid-19: European countries suspend use of Oxford-AstraZeneca vaccine after reports of blood clots. BJM. 2021;372:n699.

24. Wise J. Covid-19: how AstraZeneca lost the vaccine PR war. BMJ. 2021;373:n921.

25. Hunter PR. Thrombosis after covid-19 vaccination. BMJ. 2021;373:n958

26. Saposnik G, Barinagarrementeria F, Brown RD Jr., Bushnell CD, Cucchiara $B$, Cushman $M$, et al. Diagnosis and management of cerebral venous thrombosis: a statement for healthcare professionals from the American heart association/American stroke association. Stroke. 2011;42:1158-92.

27. Pabinger I, Grafenhofer H, Kyrle PA, Quehenberger P, Mannhalter C, Lechner $\mathrm{K}$, et al. Temporary increase in the risk for recurrence during pregnancy in women with a history of venous thromboembolism. Blood. 2002;100:149.

28. Martinelli I, Sacchi E, Landi G, Taioli E, Duca F, Mannucci PM. High risk of cerebral-vein thrombosis in carriers of a prothrombin-gene mutation and in users of oral contraceptives. N Engl J Med. 1998;338:1793-7.

29. American Heart Association, American Stroke Association Stroke Council Leadership. Diagnosis and management of cerebral venous sinus thrombosis with vaccine-induced thrombotic thrombocytopenia. Stroke. 2021;52:2478-82.

30. Shay DK. Safety monitoring of the Janssen (Johnson and Johnson) COVID-19 vaccine-United States, March-April 2021. MMWR Morb Mortal Wkly Rep. 2021;70:7018.

31. Greinacher A, Thiele T, Warkentin TE, Weisser K, Kyrle PA, Eichinger S. Thrombotic thrombocytopenia after ChAdOx1 nCov-19 vaccination. N Engl J Med. 2021;384:2092-101.

32. Schultz NH, Sørvoll IH, Michelsen AE, Munthe LA, Lund-Johansen F, Ahlen MT, et al. Thrombosis and thrombocytopenia after ChAdOx1 nCoV19 Vaccination. N Engl J Med. 2021;384:2124-30.

33. MacNeil JR, Su JR, Broder KR, Guh AY, Gargano JW, Wallace M, et al. Updated recommendations from the advisory committee on immunization practices for use of the Janssen (Johnson and Johnson) COVID-19 vaccine after reports of thrombosis with thrombocytopenia syndrome among vaccine recipients-United States, April 2021. MMWR Morb Mortal Wkly Rep. 2021;70:7017.

34. Oldenburg J, Klamroth $\mathrm{R}$, Langer $\mathrm{F}$, Albisetti M, von Auer C, Ay C, et al. Diagnosis and management of vaccine-related thrombosis following AstraZeneca COVID-19 vaccination: guidance statement from the GTH. Hämostaseologie. 2021:41:184-9.

35. Nazy I, Sachs UJ, Arnold DM, McKenzie SE, Choi P, Althaus K. Recommendations for the clinical and laboratory diagnosis of vaccine-induced immune thrombotic thrombocytopenia (VITT) for SARS-CoV-2 infections: communication from the ISTH SSC subcommittee on platelet immunology. J Thromb Haemost. 2021;19:1585-8.

36. Wolf ME, Luz B, Niehaus L, Bhogal P, Bäzner H, Henkes H. Thrombocytopenia and intracranial venous sinus thrombosis after "COVID-19 vaccine AstraZeneca" exposure. J Clin Med. 2021:10:1599.

37. Thaler J, Ay C, Gleixner KV, Hauswirth AW, Cacioppo F, Grafeneder J, et al. Successful treatment of vaccine-induced prothrombotic immune thrombocytopenia (VIPIT). J Thromb Haemost. 2021;19:1819-22. 